\title{
Kanta Loha Tablet as a Madhumeha hara drug - A single case study
}

Case report

\section{Bineesh E P1*, Prashant Bedarkar2', Patgiri B J33, Mandip Goyal ${ }^{4}$}

\author{
1.PhD Scholar, 2. Associate Professor, 3. Professor and Head, \\ Rasa Shastra and Bhaishajya Kalpana Department, \\ 4.Associate professor, Department of Kaya Chikitsa, \\ ITRA, Jamnagar. Gujarat.
}

\begin{abstract}
Rasa Shastra which explains a compendium of formulations that act as spectacular remedies for numerous diseases. Metals were used for Deha Vada (for the cure of ailments) and also for Rasayana Karma(Immunity boosting). Loha Bhasma had been using in many formulations from ancient time itself. Kanta Loha, which is superior among Loha can be considered as Magnetite. The Magnetite should contain more than $60 \%$ of iron content in it. The incineration process done according to the reference of classical Rasa Shastra classics. The controversy term "iron overload lead to diabetes" needs to be rechecked by monitoring the results of tests in diabetic patients after medication in the form of Kanta Loha Bhasma. In this article a single case study result showing towards the anti diabetic effect in human subject.
\end{abstract}

Key Words: Rasa Shastra, Kanta Loha Bhasma, Magnetite, Anti-hyperglycaemic effect.

\section{Introduction}

Kanta Loha(Lode stone) which is considered to be best among Trividha Loha divisions i.e. Kanta Loha, Teekshna Loha, Munda Loha. In AFI, Kanta Loha can be compared to magnetite iron ore which contains more than $60 \%$ of iron content in it. Rasa Ratna Samuchaya explains the use of Kanta Loha Bhasma in Madhumeha (type 2 diabetes mellitus) (1).A prolonged pharmaceutical procedures are needed to make raw magnetite iron ore samples in absorbable form. Kanta Loha tablet was prepared after prolonged procedures mentioned in the classics i.e. Shodhana (Purification), Bhanupaka, Sthalipaka, Ghrita Bharjana, Puta paka and Amriteekarana.

Diabetes mellitus is a group of metabolic disease characterised by hyperglycemia resulting from defects in insulin secretion, insulin action or both. On the basis of etiology, factors contributing to hyperglycaemia may include reduced insulin secretion decreased glucose usage and increased glucose production. Type 2 diabetes mellitus characterized by 3 pathophysiological abnormalities: impaired insulin secretion, peripheral insulin resistance and excessive hepatic glucose production. In the early stage of the disease, glucose tolerance remains normal, despite the insulin resistance, because the pancreatic beta cells compensate by increasing the insulin ouput. Gradually

* Corresponding Author:

\section{Bineesh E P}

PhD Scholar,

Rasa Shastra and Bhaishajya Kalpana Department.

ITRA, Jamnagar.

Gujarat. India.

Email Id: bineeshvaidya@gmail.com insulin resistance and compensatory hyperinsulinemia progress, the pancreatic islets become unable to sustain the hyperinsulinemic state. Post prandial glucose (PPG) levels meaning "Sugar after the meal" give more important information about how the body is able to manage glucose after a meal. Post prandial glucose numbers don't just change based on what you eat. They're also affected by how active you are, your insulin sensitivity. The ADA recommends that people with type 2 diabetes keep their PPG under 180mg/ $\mathrm{dL}(2)$. A random plasma glucose concentration 11.1 $\mathrm{mmol} / \mathrm{L}(200 \mathrm{mg} / \mathrm{Dl})$ accompanied by classic symptoms of DM (Polyuria, polydipsia, weight loss) is sufficient for the diagnosis of DM.

\section{Aim}

To monitor the efficacy of Kanta Loha Bhasma Tablet in the signs and symptoms of type 2 diabetes (Madhumeha).

\section{Materials and Methods Study setting}

OPD (Outpatient Department) of Rasa Shastra \&Bhaishajya Kalpana department, ITRA, Jamnagar, Gujarat, India. The study was started after obtaining the ethical approval from Institutional Ethics committee, ITRA, Jamnagar and the study was registered in CTRI Ref.No.CTRI/2020/05/025358.

\section{Case Study}

A 59-year-old female patient having symptoms of polyuria, turbid urine, polyphagia, polydipsia, numbness in the palms and soles, excessive perspiration, weakness, cramps in calf muscles for 1 year had chosen for the study. 


\section{History of present illness}

The patient was apparently normal before one year. She had sudden onset of increased frequency of nocturnal urination and polydipsia since before one year. She did the laboratory investigations to rule out the disease. She found elevated glucose level and took allopathic medication for the same. She approached here in order to stop continuous use of antihyperglycemic medication.

\section{Treatment History} months.

Metformin $1(\mathrm{OD})$ at early morning since 6

\section{History of Past illness}

The patient had no history of hypertension and any other systemic diseases.

\section{Family History} diabetes found.

No any relevant family history of type 2

Table:1 Personal History During Healthy Days (VaiyaktikaVrittanta)

\begin{tabular}{|l|l|}
\hline Micturition & Day time 6-8times, At night 3-4 times \\
\hline Bowel habit & Irregular -1 times/2 day \\
\hline Sleep & $\begin{array}{l}\text { Disturbed sleep due to frequent } \\
\text { nocturnal urination. } \\
\text { At night 2-3 hours } \\
\text { Day time-2 hours. }\end{array}$ \\
\hline Addiction & No any addiction \\
\hline $\begin{array}{l}\text { Blood } \\
\text { Pressure }\end{array}$ & $124 / 84 \mathrm{mmHg}$ \\
\hline Pulse rate & $74 / \mathrm{min}$ \\
\hline $\begin{array}{l}\text { Respiratory } \\
\text { rate }\end{array}$ & $18 / \mathrm{min}$ \\
\hline
\end{tabular}

\section{Systemic Examination}

No any abnormality detected.

\section{Clinical findings}

\section{Ashtavidhapariksha}

Ashtavidhapariksha (Eight-fold classifications) has been mentioned in Table 2 .

\section{Table 2: Ashtavidhapariksha}

\begin{tabular}{|l|l|}
\hline Nadi & Dosha -KaphaVataja, Regular. \\
\hline Mutra & Day time 8-9 times, At night 3-4 times \\
\hline Mala & 1time in 2 day/Katina. \\
\hline Jihva & Nirama \\
\hline Shabda & Spashta \\
\hline Sparsha & Ruksha \\
\hline Drik & Vikruta \\
Akriti & Madhyama
\end{tabular}

Diagnostic focus and Assessment:

Assessment Criteria:

Subjective Parameters

- Prabhuta Mutrata (Polyuria)
- Avila Mutrata (Turbid urine)

- Kshudhadhikya(Polyphagia)

- Trishnadhikya (Polydipsia)

- Kara-Pada-Tala Daha (Burning sensation in palms \& soles)

- Swedadhikya (Excessive perspiration)

- Daurbalya (Weakness)

- Pindiko-udveshtana (Cramps in calf muscles).

Assessment criteria of chief complaints

Table :3 Assessment criteria of chief complaints

\section{Symptoms}

Prabhuta Mutrata (Polyuria)

$3-5$ times per day, rarely at night 0

$6-8$ times per day, $1-2$ times per night $\quad 1$

$9-11$ times per day, $3-4$ times per

night

More than 11 times per day, more than $4 \quad 3$ times per night

\section{Avila Mutrata (Turbid urine)}

Crystal clear fluid

0

Faintly cloudy or smoky (turbidity barely 1 visible)

Turbidity clearly present but newsprint 2

easily read through test tube

Newsprint not easily read through test 3

tube

Newsprint cannot be seen through test 4 tube

\section{Kshudhadhikya (Polyphagia)}

As usual

Slightly increased $(1-2$ meals $)$

Moderately increased ( $3-4$ meals)

Trishnadhikya (Polydipsia)

Feeling of thirst $7-9$ times/24 hours,

either/or

Intake of water $5-7$ times/24 hours

with quantity $1.5-2.0$ liter/24 hours

Feeling of thirst 9 - 11 times/24 hours,

either/or

Intake of water 7 - 9 times/24 hours with

quantity $2.0-2.50$ liter/ 24 hours

Feeling of thirst $11-13$ times/24 hours,

either/or

Intake of water $9-11$ times/ 24 hours

with quantity $2.50-3.00$ liter/24 hours

Feeling of thirst $>13$ times/ 24 hours,

either/or

Intake of water $>11$ times/24 hours with

quantity $>3.00$ liter/24 hours

\section{Kara-Pada-Tala Daha (Burning sensation in palms}

\& soles)

No Daha

Hasta -Pada-Tala Daha found

0

occasionally,mild, bearable

Hasta -Pada-Tala Daha continuous but 2

bearable \& not severe

Hasta -Pada-Tala-Daha continuous and 3

severe \&unbearable

Swedadhikya (Excessive perspiration)

Sweating after heavy work and fast 0

(1)

movement or in hot weather 
Profuse sweating after moderate work and movement

Sweating after little work and movement (stepping ladder etc.)

Profuse sweating after little work and movement

Sweating even at rest or in cold weather

Daurbalya (Weakness)

No fatigue

Noticeable fatigue, not affecting daily routine

Noticeable fatigue, moderately affecting daily routine

Noticeable fatigue, markedly affecting daily routine

\section{Pindiko-udveshtan (Cramps in calf muscles)}

No cramps

Cramps after walking more than $1 \mathrm{~km}$.

Cramps after walking $3 / 4 \mathrm{~km}$

Cramps after walking $1 / 2 \mathrm{~km}$

Inability in walking even $1 / 2 \mathrm{~km}$

1

2

3

4

0

1

2

3

3

\begin{tabular}{l|}
\hline 0 \\
1 \\
2 \\
3 \\
4
\end{tabular}

\section{Objective Parameters}

\section{Laboratory Investigations}

-Hematological- Hb (gm \%) RBC, TLC, DLC,

Platelet, ESR, PCV

-Bio-chemical-

Diabetic profile

Lipid Profile

\author{
Hepatic profile \\ Renal Profile \\ -Urine routine examination
}

\section{Therapeutic intervention}

Treatments given to the patient have been enlisted in Table 4.

\section{Follow up}

After completion of treatment, the patient was followed up for 7days. Patient showed marked relief in the signs and symptoms and no any new complaints were reported during the $7^{\text {th }}$ day of follow up.

\section{Results}

After $14^{\text {th }}$ day of assessments, variations in results were found on each symptom associated with Madhumeha (Type 2 Diabetes mellitus). Results of the treatment were tabulated and analyzed. Patient got relief in signs and symptoms with gradual improvement. Assessment on each considering symptom of Madhumeha (Type 2 Diabetes mellitus)has been presented in Table 5 and 6.

\section{Outcome}

It was observed that after 5 days of treatment, all the signs and symptoms were markedly relieved.

Table 4 : Posology of treatment protocol

\begin{tabular}{|c|c|c|c|c|}
\hline Sr.No & Drug & Dose & $\begin{array}{c}\text { Mode of } \\
\text { Administration }\end{array}$ & Duration \\
\hline 1 & KantalohaTablet & $\begin{array}{l}315 \mathrm{mg}[250 \mathrm{mg} \mathrm{Kanta} \mathrm{Loha} \mathrm{Bhasma}+65 \mathrm{mg} \\
\text { Triphala ghana }](1 \mathrm{tab} \text { twice daily before food })\end{array}$ & Oral & 15 Days \\
\hline
\end{tabular}

Table 5: Assessment on considering symptoms of Madhumeha (Type 2 Diabetis melitus)

\begin{tabular}{|c|c|c|c|}
\hline Sr.No & Signs and Symptoms & $\begin{array}{c}1 \text { st Day } \\
\text { (Before Treatment) }\end{array}$ & $\begin{array}{c}\text { After treatment } \\
15^{\text {th }} \text { day }\end{array}$ \\
\hline 1 & Prabhuta Mutrata (Polyuria) & 2 & 0 \\
\hline 2 & Avila Mutrata (Turbid urine) & 2 & 0 \\
\hline 3 & Kshudhadhikya(Polyphagia) & 1 & 0 \\
\hline 4 & Trishnadhikya (Polydipsia) & 2 & 1 \\
\hline 5 & Kara-Pada-Tala Daha (Burning sensation in palms \& soles) & 2 & 1 \\
\hline 6 & Swedadhikya (Excessive perspiration) & 2 & 0 \\
\hline 7 & Daurbalya(Weakness) & 2 & 0 \\
\hline 8 & Pindiko-udveshtana (Cramps in calf muscles). & 1 & 0 \\
\hline
\end{tabular}

Table 6: Laboratory Investigations

\begin{tabular}{|c|c|c|c|c|c|}
\hline Parameter & & & BT & AT & Follow up ( 7 days) \\
\hline \multirow{12}{*}{ Hematological } & $\mathrm{Hb}(\mathrm{gm} \%)$ & & 14.4 & 13.5 & 14 \\
\hline & $\mathrm{RBC}$ & & 4.82 & 4.58 & 4.52 \\
\hline & TLC & & 7300 & 8090 & 8090 \\
\hline & DLC & Neutrophil & 57 & 53 & 54 \\
\hline & & Lymphocytes & 32 & 34 & 32 \\
\hline & & Eosinophils & 6 & 8 & 5 \\
\hline & & Monocyte & 5 & 5 & 5 \\
\hline & & Basophils & 0 & 0 & 0 \\
\hline & Platelet & 292000 & 28300 & 28300 & \\
\hline & ESR & 28 & 18 & 12 & \\
\hline & PCV & 44.4 & 40.6 & 40.6 & \\
\hline & Diabetic profile & FBS & 149 & 147 & 138 \\
\hline
\end{tabular}




\begin{tabular}{|c|c|c|c|c|c|}
\hline \multirow{17}{*}{ Bio-chemical } & & PPBS & 261 & 152 & 150 \\
\hline & \multirow[t]{5}{*}{ Lipid Profile } & Sr Total Cholesterol & 261 & 278 & 270 \\
\hline & & Sr Triglyceride & 134 & 130 & 130 \\
\hline & & HDL & 64.3 & 64 & 64 \\
\hline & & VLDL & 26.8 & 27.4 & 27 \\
\hline & & LDL & 169.9 & 165 & 159 \\
\hline & \multirow[t]{8}{*}{ Hepatic profile } & Sr. Bilirubin $(\mathrm{T})$ & 0.26 & 0.42 & 0.40 \\
\hline & & Sr. Bilirubin (D) & 0.18 & 0.15 & 0.15 \\
\hline & & SGOT & 14 & 16 & 14 \\
\hline & & SGPT & 19 & 17 & 17 \\
\hline & & $\begin{array}{c}\text { Alkaline } \\
\text { Phosphatase }\end{array}$ & 85 & 71 & 70 \\
\hline & & Total Proteins & 7.15 & 7.65 & 7.45 \\
\hline & & Albumin & 3.97 & 3.85 & 3.80 \\
\hline & & Globulin & 3.18 & 3.15 & 3.12 \\
\hline & \multirow[t]{3}{*}{ Renal Profile } & Sr. Creatinine & 0.98 & 0.92 & 0.90 \\
\hline & & Sr. Uric acid & 3.52 & 4.17 & 4.10 \\
\hline & & Blood Urea & 20 & 20 & 20 \\
\hline \multirow{11}{*}{ Urine } & \multirow[t]{4}{*}{ Physical } & Colour & Whitish & Pale yellow & Pale yellow \\
\hline & & Appearance & Turbid & Clear & Clear \\
\hline & & Reaction & Acidic & Acidic & Acidic \\
\hline & & Sp. Gr. & QI & QI & QI \\
\hline & \multirow[t]{2}{*}{ Chemical } & Albumin & Present & Absent & Absent \\
\hline & & Sugar & Present & Absent & Absent \\
\hline & \multirow[t]{5}{*}{ Microscopic } & Pus cells & $4-5$ & Absent & Absent \\
\hline & & $\mathrm{RBC}$ & Absent & Absent & Absent \\
\hline & & Epi cells & $6-8$ & $1-2$ & $1-2$ \\
\hline & & Casts & Absent & Absent & Absent \\
\hline & & Crystals & Absent & Absent & Absent \\
\hline
\end{tabular}

Table 7: Rasa Panchaka of Kantaloha Tablet(3),(4),(5),(6)

\begin{tabular}{|c|c|c|c|c|c|c|c|}
\hline No & Drug & Botanical & Rasa & Guna & Virya & Vipaka & Karma \\
\hline 1 & Kantaloha & $\begin{array}{l}\text { Magnetite iron } \\
\text { ore }\end{array}$ & $\begin{array}{l}\text { Tikta,MadhuraK } \\
\text { ashaya }\end{array}$ & $\begin{array}{l}\text { Sheeta, } \\
\text { Guru, } \\
\text { Snigdha }\end{array}$ & Sheeta & Madhura & Tridosha Shamaka \\
\hline 2 & Hareetaki & $\begin{array}{l}\text { Terminalia } \\
\text { chebula Retz. }\end{array}$ & $\begin{array}{l}\text { Pancha rasa } \\
\text { ( } K \text { a s h a y a } \\
\text { pradhana and } \\
\text { Lavanavarjita) }\end{array}$ & $\begin{array}{l}\text { Laghu, } \\
\text { Ruksha }\end{array}$ & Ushna & Madhura & $\begin{array}{l}\text { Tridoshaghna } \\
\text { Chakshushya } \\
\text { Rasayana } \\
\text { Lekhana }\end{array}$ \\
\hline 3 & Amalaki & $\begin{array}{l}\text { Embilica } \\
\text { offic in a lis } \\
\text { Gaertn }\end{array}$ & $\begin{array}{l}\text { Pancha rasa } \\
\text { (Amla pradhana } \\
\text { and } \\
\text { Lavanavarjita) }\end{array}$ & $\begin{array}{l}\text { Laghu, } \\
\text { Ruksha }\end{array}$ & Shita & Madhura & $\begin{array}{l}\text { Kapha pitta hara } \\
\text { Chakshushya } \\
\text { Rasayana } \\
\text { Bhedana }\end{array}$ \\
\hline 4 & Bibhitaka & $\begin{array}{l}\text { Terminalia } \\
\text { bellerica } \\
\text { Roxb. }\end{array}$ & Kashaya & $\begin{array}{l}\text { Laghu, } \\
\text { Ruksha }\end{array}$ & Ushna & Madhura & $\begin{array}{l}\text { Kapha pitta hara } \\
\text { Chakshushya } \\
\text { Rasayana } \\
\text { Bhedana }\end{array}$ \\
\hline
\end{tabular}

\section{Observation}

It was observed that the patient got marked relief from Madhumeha (Type 2 Diabetes mellitus) in 15 days. She was asked to come for follow-upafter7 days; Patient was not on any medication at that time.

\section{Discussion}

-Effect of treatment on Prabhuta Mutrata (Polyuria)

The patient had complained of frequent urination, 8-9 times per day, 3-4 times per night disturbing daily routine at first day of treatment, gradually it has been decreased to 3-5 times per day, rarely at night.

\section{-Effect of treatment on Avila Mutrata (Turbid Urine)}

Turbidity clearly present but newsprint easily read through test tube before the treatment. On $15^{\text {th }}$ day the urine appears clear.

\section{-Effect of treatment on Kshudhadhikya (Polyphagia)}

Before the treatment patient had complaints of slightly increased polyphagia. After 15 day of treatment the symptom became normal.

\section{-Effect of treatment on Trishnadhikya (Polydipsia)}

The patient had grade 2 polydipsia. After the medication the grade 1 polydipsia present. 
-Effect of treatment on Kara-Pada-Tala Daha

(Burning sensation in palms \& soles)

Before medication, Hasta -Pada-Tala Daha was continuous but bearable \& not severe. After clinical trial patient had mild burning sensation only that is also not continuous.

\section{-Effect of treatment on Swedadhikya (Excessive perspiration)}

Before the intervention the patent had sweating after little work and movement (stepping ladder etc.).After the intervention the patient felt relief.

\section{-Effect of treatment on Daurbalya (Weakness)}

The patient had weakness before the treatment. Noticeable relief in symptoms observed.

\section{-Effect of treatment on Pindiko-udveshtana (Cramps in calf muscles).}

Patient had mild cramp before the treatment. Muscle cramp were not noted after the treatment.

\section{- Changes in the glucose values}

The patient had fasting blood sugar value of 149 before the medication. Slight decrease i.e., 138 noted in FBS after the treatment. Drastic changes in the Post prandial glucose value were noted. Before the medication the value was 261, after the follow up PPBS is 150 .

\section{Mode of Action of Kanta Loha Tablet}

Kanta Loha (Magnetite) is indicated in the Madhumeha According to Rasa Vaghbhata. Kanta Loha Bhasma may act as targeted drug delivery because of its Yogavahi property. Triphala as a whole is expected to be more effective due to the combined activity of the individual components. Anti-oxidant property of Triphala arises from polyphenols, which reduces the oxidative stress by converting the reactive oxygen free radicals to non-reactive products (7).Triphala also the drugs said to act as Naimittika Rasayana which is beneficial in Madhumeha(8).

Kanta Loha Bhasma consists of super paramagnetic iron oxide nanoparticles. SPIONs are powerful glucose lowering factor that play important role in diabetic treatment. Triphala also contains bio active compounds such as Quercetin(9).It has been shown that QC treatment can enhance cognitive impairement in the diabetic rats, which may have the potential for treating neuropathy in the diabetic patients(10).Histological analysis showed that the treatment with $\mathrm{QC}-\mathrm{Fe}_{3} \mathrm{O}_{4}$ restored the shape of beta islands and increased the number of islets and their area in diabetic rats (11). Kanta Loha Bhasma along with the Triphala extract having the same effect in human samples also.

\section{Conclusion}

In the current case study there is drastic reduction in the PPBS value indicates the anti hyperglycemic action of Kanta Loha Tablet. The synergic action of Triphala and Kanta Loha may be acted as synergetic action of Qurcetin conjugated SPIONs. The human subject showed marked change in the glucose value with the 15 days of treatment. This finding may help the medical scholars to utilize this ancient herbo mineral formulation in type 2 diabetes.

\section{Scope for Further Study}

The study should be conducted in large samples as well as prolonged duration in order to monitor the anti hyperglycemic effect more clearly.

\section{References}

1. Rasavagbhata,Rasaratnasamuchaya commented by Dattatreya Ananta kulkarni, Chaukhambha publications, reprint 2010 chapt.5/96 Pp235 page no.113.

2. https://www.everydayhealth.com/hs/type 2 diabetes-management/postprandial-glucose/

3. Kulkarna DA, Rasa Ratna Samucchaya of Rasa Vaghbhata, 5/96 pp113.

4. The Ayurvedic Pharmacopeia of India, Part 1 Vol 1, Page No.47

5. The Ayurvedic Pharmacopeia of India, Part 1 Vol 1 , Page No.4

6. The Ayurvedic Pharmacopeia of India, Part 1 Vol 1 , Page No.26

7. Naik G H, Priyadarshini KI, Bhagirathi RG, Mishra B, Mishra KP, Banavalikar MM, et, al. In vitro antioxidant studies and free radical reactions of Triphala, an ayurvedic formulation and its constitutuents. Phytother Res 2005; 19:582-6.

8. Akarshini AM, Aruna. Management of Madhumeha janya Upadrava with special reference to diabetic nephropathy-a clinical study. Ayu 2014;35:378-83.

9. Belapurkar P, Goyal P, Tiwari-Barua P. Immuno modulatory effects of Triphala and its individual constituents; A review. Indian J Pharm Sci 2014; 467-475[PMC free article] [PubMed][Google Scholar]

10. Maciel RM, Carvalho FB, Olaabiyi AA, et al. Neuro protective effects of quercetin on memory and anxiogenic like behavior in diabetic rats; Role of ectonucleotidases and acetylcholinesterase activities. Biomed Pharmacother. 2016;84:559-568.

11. Shiva Ebrahimpour, Abolghasem, Esmaeili and Siamak Beheshti, Effect of quercetin conjugated super paramagnetic iron oxide nanoparticles on diabetes induced learning and memory impairement in rats. Int J Nanomedicine.2018;13:6311-6324. 